\title{
The Notion of Humankind According to the Music-pedagogical Conception of Former Socialist States, Exemplified in the Former German Democratic Republic
}

\author{
DAMIEN SAGRILLO \\ Translated by Lee A. Rothfarb
}

\section{Preliminary Remark}

Music education in the former GDR is to be understood in the framework of the development of a socialist notion of humankind. The present essay:

- offers, accordingly, less of a glimpse into the didactic models and educational approaches that are distinct from those in West Germany

- deals instead with music education as a means for developing an "ideal" socialistic human being. Education in art, athletics or other subjects could replace music

- refers to the disciplinary literature of the GDR in the years 1955-1972

- for that reason sticks primarily to the present, refers, however, repeatedly to that time period

- and instead of the conceptual combination "former GDR" uses simply "GDR"

\section{Overview of the Organization and Conception of Education in the GDR ${ }^{1}$}

\subsection{Differentiation between Cultivation and Education}

Cultivation in the GDR is the relaying or rather the acquisition of knowledge and skills, this in the sense of the process and results of cultivation. Education, by contrast, embraces the development of needs, aims, attitudes, convictions, ideals, feelings, and character traits of character. Both processes together constitute the education process. Socialistic education sees itself as "the comprehensive development of character, conducted by the revolutionary working class with socialistic awareness, occurring of its own accord in collective relationships and through engagement with the environment." It is a matter of intentional education as well as of functional education and self-education. The pedagogical mission is planned and directed by the state and the party.

\footnotetext{
${ }^{1}$ cf. Manfred Ludwigs, "Zur Organisation der Erziehung in der DDR,” in Deutsche Studien, hrsg., Karlheinz Gehrmann u. a. (Lüneburg, 1977), 125-138.
} 


\section{Music AND Politics Summer 2008}

1.2 Education in collectives and with standardized objectives

Socialist education occurs in collectives, groups of people joined together who carry out a specific function. The student is supposed to be educated by the collective to become a responsible socialist citizen. There are several subordinated and coordinated collectives, which are operative in the arena of academic education. (e.g. teacher collectives, student collectives, etc.). Additionally, different collectives in the organizations of schools occupy an intermediary position, that is, primarily the Free German Youth (FDJ, Freie Deutsche Jugend) and parents' council. Education, monitored by the state, is uniform in the GDR, with the goal of producing a functioning socialist character through the pedagogical process, which promotes uniformity of knowledge acquisition and ideological education. A first methodological step provides the pedagogue with a catalog of the desired characteristics of the socialist character, which illustrated the constituent goals of a socialist education. A second methodological step is concerned with creating the conditions for realizing uniform education in the GDR.

\subsection{Some important aspects of academic education in the GDR}

A schedule of work and class leader's schedule contain determinations for the realization of, above all, the political and ideological tasks of education. Usually they are produced annually. The educational system arranges for a hierarchy of commendations for the pedagogical collective, which in the case of appropriate performance will be granted to the faculty. For students, such a system also exists, which however also provides for penalties. Significantly, value is also placed on influencing society in connection with commendation and penalty, on whose appointed measures colleagues, students, as well as parents and their colleagues are informed.

\subsection{Extra-curricular educational activity}

The family, as the most primal collective, is supposed to work closely with the school, the FDJ, and the enterprise. It is expected that parents participate actively in societal life, while education is carried out to a great extent as the organization of that life. Additionally, radio, film, television, press, publishers, and art, as societally contracted institutions, bear a portion of the responsibility in the pedagogical process. According to the understanding of pedagogy in the GDR the organization of education aims at socializing, "for an educator is anyone who on behalf of the worker class consciously and in direct interpersonal relations engages in the development of character traits in others. ${ }^{2}$ Pedagogy in the GDR advocates for a condition of societal organization, an essential attribute of the socialistic character. Accordingly, a large measure of latitude for individual freedom is lost for those being educated as well as for the educator. The private domain is eliminated entirely.

\footnotetext{
${ }^{2}$ Ludwigs, "Zur Organisation der Erziehung in der DDR,” 136.
} 
1.5 The (official) conception of the rise of societal development in the GDR

In the GDR, societal development is to be achieved by cultivating the standard of the worker class. The goal is the familiar multi-faceted development of character (see above), with the image of the socialistic being as the leading idea. A higher qualification is supposed to assist in mastering the growing challenges of scientific and technical renewal. By contrast, "every limitation of the image of the socialistic being to a purely specialized qualification and cultivation is to be rejected with respect to the demands of the technical revolution. ${ }^{3}$ Further, the socialistic individual should be educated to take part in the leadership of the state and society, and to acquire a newly defined relationship to art and culture. "The image of human beings is enriched through the multiplicity and depth of aesthetic training and of artistic experiences...which mark their historical consciousness, their imagination, their emotions, theory passions, their observational talent, their sense for beauty, and therefore their image of the world. ${ }^{4}$

\section{Social image of the human being and music education}

\subsection{General Preliminary Considerations}

According to socialistic interpretation, art was used in the past as a means of solidifying civic authority. The educational aspect consisted in disguising that authority through a particular acoustical signal and in that way to maintain the appropriate measure of reason. "The merely intoxicating-emotional character of music of many time periods and occasions...plays an often dominant role with primitive musical cultivation. ${ }^{5}$ The acoustical signal can in part be transferred to actual music. Even today, still, it pursues tangible economic interests across generations-if not political ones-and cannot be eliminated from the social environment of the younger generation. That circumstance is reinforced by the cult status of some performers and their songs. By means of targeted cultivation, Marxist aesthetics of art attempts to make music a requirement for artistic education not only for a small circle but for the broad public mass. The three pillars-creator, performer, public-are viewed in part on one level with the societal relationship between production, reproduction, and consumption. Accordingly, art is supposed to be a reflection of reality. Consequently, there can be no isolation and privatization of the experience of art. ${ }^{6}$ Logically, in matters of musicology and music education, the standpoint of "l'art pour l'art" must be abandoned. The goal of education must be to determine the positioning of music within society, and to understand and accept art and science as products of societal consciousness, that they flourish when productive forces develop in parallel with them.

\subsection{Aesthetic cultivation and music education}

\footnotetext{
${ }^{3}$ Jürgen Schmollack, "Sozialistisches Menschenbild und sozialistische Erziehung," in Pädagogik (Berlin/O, 1968), 833.

${ }^{4}$ Paul Michel, "Die Aufgaben der Musikerziehung im System der sozialistischen Allgemeinbildung," in Musik in der Schule (Berlin/O, 1969), 5f.

${ }^{5}$ Walther Siegmund-Schultze, hrsg., Ziele und Aufgaben der sozialistischen Musikerziehung (Leipzig, 1967), 104.

${ }^{6}$ cf. Karl Marx, Deutsche Ideologie, Feuerbach WWII, 23 (Basis/Überbau-Modell) and Siegmund-Schultze, Ziele und Aufgaben der sozialistischen Musikerziehung, 50.
} 
Aesthetic cultivation has its place in the system of general socialistic education.

General cultivation means the acquisition of contents of the native language, mathematics, natural sciences, technology, social sciences, foreign languages, physical fitness, and arts, which are integrated into a comprehensive system through overarching considerations and tasks, linked to the universal character, of an ideologico-philosphical, of a spiritual, poly-technical, physical and aesthetic cultivation and education. ${ }^{7}$

Aesthetic education within the socialistic system of education is therefore not a luxury. Rather, its absence would throw into question the entire concept of such education insofar as it, like other areas, were to be neglected. Supplementary areas would have to be optimized in order to guarantee analogous, proportionate progress of all parts of the system. This systemic interdependence applies not only to the supplementary areas and to the coordination of the cultivation. No, the systemic aspect must contribute to the realization of constructing societal consciousness on the part of music education. According to Michel the systemic aspect must contribute to the realization of constructing societal consciousness on the part of music education. Aspects of aesthetic cultivation reach into many branches of the domain of cultivation and must be consciously recognized and promoted. $^{8}$

2.3 Music as an emotive, awareness-building and creative force

In addition to acquiring knowledge, the evoking of emotions and attitudes should be promoted in the work of education. Accordingly, music would be an emotional supplement to the process of gaining knowledge and would serve as a means for personal development and as an aid to thinking. ${ }^{9}$ The assertion does not apply that music is necessary compensation for emotion-free technologizing [of life], with the help of which humankind can escape from its real environment. The argument that technological development first allows for the possibility of the actual human element, i.e., culture and art is not as predominant as the interpretation that scientific and technological renewal, as well as cultural revolution, are a mutually complementary system, where the cultural level is responsible for the speedy development of productive forces (see above), on the one hand, and where, on the other, culture and art would become matters for the folk in the course of the development. The task of music in particular, and of culture in general, would be "the intellectual, culture, and artistic mastery of human relations with the modern technology of our times. $" 10$

According to socialistic interpretation, in addition to conditions for regulating societal and interpersonal relations, music education brings about further conditions for developing general creative forces through activating the sense of beauty and the communication of aesthetic perspectives-this, however, only after a certain active degree of involvement with that art that could be useful for scientific progress for technical concepts and innovations. Related research outcomes confirm that, strange as it may seem, capabilities gained through music education have an effect on

\footnotetext{
${ }^{7}$ Michel, "Die Aufgaben der Musikerziehung," 5.

${ }^{8}$ cf., ibid.

${ }^{9}$ Günther Diezel, "Sozialistisches Menschenbild und Musikerziehung," in Musik in der Schule (Berlin/O, 1971), 187f.

${ }^{10}$ Klaus Gysi, "Die Kunst im Kampf für eine sozialistische Gemeinschaft, Auszug aus einer Rede," in Neues Deutschland 19 (Oktober 1968).
} 
the mastery of other complicated activities. With reference to schools, this positive correlation between music-intellectual and scientific-technical capabilities shows that musical pupils can also keep up with the pace in other subjects. ${ }^{11}$ There is no confirmation of a negative correlation between musical and mathematical capabilities, which is customarily expected.

"Music education is not merely an aesthetic concern. It is an operational force of the highest rank which stimulates and activates the intellectual potency of individuals." 12 The question poses itself, of course, whether musical talent should sooner be understood as existing within a complex of capabilities rather than being a precondition for other talents.

\subsection{Self-criticism and suggestions for improvement}

The goal of music education is designed to awaken the aspiration for musical activity and to encourage personal and societal development through music. However, there remains a long path even in the GDR before reaching that goal. Michel complains that pupils do not take music education as seriously as desired. ${ }^{13}$ Some see music as completely useless for living life. Other pupils consider involvement with music as not absolutely necessary. The largest number, however, acknowledge only the entertainment factor in music. Socialistic education seems to bear fruit in only a small faction of the pupils. That faction commits itself to the character-building dimension of music education. There is also the objection that parents do not assign very much significance to this subject, and that even the faculty diminishes music education as an insignificant accessory subject. In order to guarantee a better choice of music-educational offerings musicologists and the Ministry for National Education should work together with the Association of German Composers. Targeted compositions-in this case, songs with a specific thematic content-would have to be provided for music education. Workshop conversations of pupils with composers, performers, and musicologists should promote mutual understanding. The possibility of actualizing ideological education through music would have to be acknowledged and exploited. Music analysis with Marxist-Leninist background should be required of the educators. An interdisciplinary coordination of music instruction with history, social studies, German language and literature, art education, as well as foreign languages should help in recognizing knowledge and insights about developmental tendencies of society. Conversely, the application of historical and political knowledge should assist in tapping into the content of ideas in musical art works. Finally, reality will be represented through music-aesthetic means. Extra-curricular music education has been realized in the FDJ and in the pioneer movement "Ernst Thälman." Some songs that arose there should be used in music education because of the power of their political message and their timeliness.

\footnotetext{
${ }^{11}$ Paul Michel, "Musik und Hörer in unserer Zeit. Psychologische und pädagogisch-methodische Grundfragen der Musikverbreitung," in Deutscher Kulturbund (Berlin/O, 1967), 55ff.

${ }^{12}$ Michel, "Die Aufgaben der Musikerziehung," 8.

${ }^{13}$ Ibid., 9ff.
} 


\subsection{Discussion of the needs of pupils}

A task of music pedagogy in the GDR that is not to be neglected is education toward the proper interaction with the offerings of the mostly West German radio stations which, for the socialist state, exert an objectionable influence on society. "The systems dealing with music listening should never neglect that our school-age youth are still under the influence of broadcast mass media deliberately instituted by West German state-monopolized cultural mechanisms for manipulating people. ${ }^{14}$ Additionally, must be added that this quotation refers to the musical portion of radio broadcasts, and that ideological manipulation through music has greater difficulty thriving than through the spoken word. In this case, further coordination, this time between schools and radio, should help to eliminate the problem of so-called musical decadence-meaning pop music, by deliberately dealing in this manner with the listening ideals of the youth. According to the listening habits of pupils, dance music and music for entertainment should be invested with content tied to values.

\subsection{Training and continuing education of the music teacher}

In keeping with the demand for qualitative change in the training and continuing education of faculty, they should be persuaded to engage and implement the fundamental goals of the curricula. In that regard, musicology should furnish theoretically founded, practicable advice for the mastery of such tasks. Music education would in this way develop away from a descriptive, historically oriented subject to a theoretically based discipline, which holds to the humanistic tradition propagated by socialism, and which plans, determines, and guides socialistic life of the present. The unified periodical "Music in the School" should function as a mirror which reflects the true reality of the efforts, deeds, facts, and results.

\subsection{Music schools and promoting the talented}

The general socialistic education of the musical type is differentiated in music schools. The curricula take it to mean "a furthering and deepening of obligatory instruction that can be optimally suited to societal requirements, especially the requirements of future specialized training and the schooling of individual talents and views." 15

The main tasks of music schools consists, on one hand, in the dissemination of the artistic culture of the nation and of general music education and, on the other, of identifying talent and training of the gifted to develop the professional musician, which is achieved through promoting the highly gifted and through training in special schools of music. Identifying talent is facilitated by cooperation of the relevant agencies. Research programs on the forms of determining musical talent have been initiated for determining musical talent after it was recognized that western testing, which had been used to date, did not exactly fit into the overall conception of local music pedagogy. They want to open the doors to international competitions with scientific training methods similar to

\footnotetext{
14 Ibid., 20.

15 "Zur Bilanzierung des Standes der Theorie der Allgemeinbildung," in Pädagogische Forschung; Wissenschaftliche Nachrichten (Berlin/O, 1968), 14. No author given.
} 
those in the domain of athletics. Higher educational challenges likewise demand a scientific foundation. The teaching and learning process should be more rational. Obsolescent schematism must yield to certain scientific principles. ${ }^{16}$

\subsection{Example of a curriculum and suggestion for its implementation}

At this point, an example is to be presented of how the curriculum for piano would be realized in according to a socialistic conception. The line of argumentation is to be reproduced in some selected quotations. ${ }^{17}$ Piano instruction only fulfills its purpose if the learned material is applied societally. "In order to be effective in the folk-related domain, they (pianists) must be educated to be socialistic personalities."18

The training and educational goals of piano instruction are precisely defined in the framework of the educational system. "They include the education of the pupils up to a definite class level, to socialistic patriotism, to intolerance and the fight against manifestations of middle-class ideology and decadence, to love, to work, and to learning, to a high feeling of responsibility to society, in addition to set high expectations of oneself, to loyal friendship with the Soviet Union, and to proletarian internationalism. I would also add the development of joy in music and of music as a condition for the readiness to permit the acquired capabilities to be effective in societal life." ${ }^{19}$ The fact that piano instruction is to be covered poses the question whether these ever recurring, flowery and, in this context, tasteless expressions where there is never talk of discipline-specific issues, have not had a dissuasive effect on the party-line readers in the GDR. Nevertheless, some inessential instrumentspecific and general music-training tasks are laid out, and ways of realizing educational goals are illustrated, above all in placing value on analytical issues in the repertoire to be played, which degenerates in the familiar direction of ideological propaganda. "The point of departure for practicing, as the centerpiece of internalizing a musical work must be music-aesthetic ideas. These are produced during orientation by means of analysis of the work. ${ }^{20}$ How analysis is carried out has already been discussed.

In the remainder of the essay, the author presents a precise syllabus with the musical works to be studied, and prepares an analysis for each work and a guide for practicing. However, he is not successful of producing, with a line of argumentation, a connection between piano instruction and ideological education. Rather, he constantly repeats the thesis of unity between art education and socialistic training of individuals. His choice of literature for study consists only-and who would be surprised-of musical works of contemporary socialist composers. He concludes: "With all the efforts in this direction (unity of art and ideology), we should never forget that education through music without education toward music is not possible. Let us educate our pupils to love our contemporary socialist art. Then let us forget a strong weapon in the battle against middle-class

\footnotetext{
${ }^{16}$ On the relationship between music education and science, I refer to Part III,1, section 4.

${ }^{17}$ cf. Hellmut Hübner, "Bildungs- und Erziehungsaufgaben des Klavierunterrichts in der Musikschule und die Möglichkeit ihrer Erfüllung durch die Arbeit an Werken des sozialistischen Gegenwartsschaffens," in Musik in der Schule (Berlin/O, 1969), 73-81.

${ }^{18}$ Hübner, "Bildungs- und Erziehungsaufgaben," 73.

${ }^{19}$ Ibid., $73 \mathrm{f}$.

${ }^{20}$ Ibid., 75.
} 


\section{Music AND Politics Summer 2008}

ideology and decadence. ${ }^{21}$ On reading this essay, the fundamental question arises: Were texts of this type not works by system advocates full of profiled anger rather than of pedagogues interested in art education?

\section{Music Education as a Socio-political Function}

It is necessary at this point to deal with an essay that bears the same title as this chapter, and which originates with a West German author. He attempts to examine comparatively West and East German music education. $^{22}$

\subsection{Comparison between East and West}

It will be established here, in general, that when education falls within the sphere of influence of the state and its government, the government cannot be in contradiction to the principles of the state and its ideas. That fact proves true strongly in a totalitarian state system and extends necessarily to all of its component systems. The author therefore compares the guidelines for music education of elementary schools in the state of North Rhine Westphalia with those of the GDR. The guidelines for North Rhine Westphalia make clear that music is taught for music's sake. By contrast, the analogous text in the GDR-which is substantially longer-requires education toward the goal of humanity and of the state citizen. The desire for acquiring knowledge can hardly be deduced by reading the guidelines. Instead the text engages in polemics against the conception of western music education. Although both curriculum plans speak initially of aesthetic education and of general training of the character, it soon becomes apparent that in the GDR personality can be understood only as a member of the population, and that music education only serves the required goals of education (see above). It is clear, therefore, that music education serves neither music nor the child but rather society and the state. It is striking that those dealing with curricula expend the most effort in the GDR to scientifically establish the elementary foundations of music education, as though in that effort lay the research into psychological, methodological, and pedagogical questions, the investigation of systems for learning sight-singing and of questions about children's awareness of melody, among other things, in order in that way more accurately to identify discipline-specific problems. In that area of academic work, owing to its relative innocuousness, the state grants scholars wide latitude because it cannot do great damage. Genuine democrats are produced there. Of course the boundaries marked out cannot be overstepped, and Soviet-oriented pedagogy must be closely adhered to.

\subsection{Extra-curricular music education}

As in the former Federal Republic, music education in the overall educational plan is merely a peripheral matter and is relegated to the bottom rank. However, because schooling in the GDR is primarily oriented toward achievement, the achievement principle holds in music instruction as

\footnotetext{
${ }^{21}$ Ibid., 81.

${ }^{22}$ This text originates in the former Gesamtdeutschen Institut in Bonn. The author, place and year of publication are not indicated and could not be determined. However, we can easily recognize that it was written in the mid-1950s.
} 
well. Efforts to direct extra-curricular music education are on fertile soil in the GDR. In youth organizations, for example, music and the cultivation of the folksong are emphasized. Further, municipal music schools are established. The author justifies the necessity for the socialistic state to maintain such schools in three points: $:^{23}$

1. the framework of socio-political educational possibilities should be expanded; musiceducational aspects are secondary;

2. educational privilege should be reduced

3. private music teachers should be absorbed and placed under state control

The author justified the use of municipal music schools as follows. ${ }^{24}$

1. music pupils (children of workers and farmers) receive a supplementary and comprehensive music education

2. the foundation of a broad cultivation of music is thereby realized

3. a systematic screening for talent can be undertaken in cooperation with public schools and municipal music schools

\subsection{Conclusion}

Overall, the author determines that the organization of municipal music schools is on firm footing, and that efforts are in the making to put music education more in the service of music. Additionally, however, he does not exclude the possibility that a certain strategy is behind the scene that endeavors to disguise the propaganda more cleverly. His conclusion: "As little as we in the West can adopt from this, we should as fully and seriously observe the forms that...develop in the area of music education and cultivation. There is no reason for us to be satisfied with the developments and conditions in the Federal Republic of Germany." 25 However, he indicates that despite existing drawbacks a broad, diversified spectrum exists in professional journals and publishing houses for publication of music. In the GDR, by contrast, a single track prevails: there is only one professional journal and only one state publisher.

\section{Music Reception, Music Creation and Musical Inheritance}

\subsection{Music reception in the $\mathrm{GDR}^{26}$}

Music education must make us aware of the forms and contents of music, because active musical understanding is hindered owing to lacking education or inferior music. Music education should therefore enable and promote active aural experience. The demand for a musically trained nation has many facets. It is important that music of the past and of the present be assimilated equally. Musical hearing has to elevate itself from the most naïve form of reception. To that end, a

\footnotetext{
23 cf. Hübner, "Bildungs- und Erziehungsaufgaben," $32 \mathrm{f}$.

24 cf. Ibid., 36 f.

25 Ibid., 40.

${ }^{26}$ cf. Siegmund-Schultze, Ziele und Aufgaben der sozialistischen Musikerziehung, 75ff und "Die Rolle des musikalischen Erbes im Sozialismus," in Musik in der Schule (Berlin/O, 1963), 15-33 and 53-64.
} 
hierarchy of reception levels is to be established that differentiates between purely emotional assimilation, intellectual grasp, and educational effect. Music is understood according to the relevant epoch and the relevant societal relationships. Religious music is often manipulated as a humanization of the "Christ legend." An effort exists to include historical and aesthetic knowledge to the assimilation of music. That is a challenge for all music professionals to understand themselves as pedagogues. So-called pop music is a big problematic area in music reception in the GDR. "Music instruction must deal critically with the widest variety of opinions of pupils, thus for example with the problems of decadence, of kitsch, of dance and entertainment music ("hits"), of jazz. $^{27}$ The music educator is required to discuss pop music and thereby to counteract the ostensible manipulation on the part of radio stations in the West. An appeal goes out to composers to create pop music tied to values, to orient themselves according to eighteenth and nineteenthcentury dance music, to incorporate also love of homeland and humor by means of engaging melody, interesting rhythm, which, however, should not be to excessive for making this genre societally useful. Music education should attempt to sharpen the judgment of pupils vis-à-vis the quality of pop music by attempting to mindless, fanatic intoxication.

\subsection{Music Creation ${ }^{28}$}

In the GDR, artists and workers are in a creative reciprocal relationship out of which new art works should arise. In that connection it should not be forgotten that both classes have common and foundational interests to represent, though the leadership role in this two-sided relationship of trust falls to the working class "by force of "objective facts." 29 That leadership role of the working class is justified through a few arguments. Art is the property of the folk. The working class which, as is believed in the GDR, liberated art from its dependence, plays and active role in the development of art and culture. Through the SED [Socialist Union Party], the working class formulates intellectual and cultural expectations and presses for creative activity. Modifying the character of labor requires more intellectual work. The folk masses should participate more in culture, as well as feel drawn to intellectual and cultural demands. Stamped by this development, the new addressee of artistic creativity should be the laborer. "In life and in the struggle of the working class itself, new heroes mature to whom literary and artistic works owe their stimulus."30 Additionally, the demand is made that the production of this "aesthetic experience of work,"31 along with the personage of the worker, becomes the object of art works in order to fill out the "white spot on our map of socialistic art."32

The tenor of this art work is its influence on societal life and the intellectual and cultural development of humankind and of interpersonal relations. To do that, the artist must understand the logic of societal development and must devote himself to the intensive study of Marxism-

\footnotetext{
${ }^{27}$ Paul Michel, "Musik und Jugend,” in Musik und Gesellschaft (Berlin/O, 1969).

28 cf. Kurt Hager, “Arbeiterklasse und Künstler,” in Musik in der Schule (Berlin/O, 1972).

${ }^{29}$ Hager, “Arbeiterklasse und Künstler,” 314.

${ }^{30}$ Ibid., 316.

${ }^{31}$ Ibid., 317.

32 Ibid.
} 
Leninism. Practical relations between both groups should given the artist insight into the thinking and feeling of the laborer. Despite these demands on the artist, the responsibility of his creativity resides solely with him. His art work must serve socialism. It should be stimulation as well as facilitate entertainment and self-knowledge.

The Socialist Union Party demands of the artist political consciousness of the state and political maturity, and instates a relationship of trust only when he demonstrates to the Party faithfulness to principles, honesty and loyalty. The demand goes out to musicologists and art critics to demonstrate a high degree of socialistic partisanship and personal engagement in their judgments, to nuance their evaluations, and to have understanding for the difficulty of the creative process.

\subsection{The Inheritance}

"The socialistic-realistic account of ancient classical works begins from the view that humanity has elevated those works that artistically shape their advancements toward an ever more powerful, delicate and bold humanity. The accounting thus emphasizes progressive ideas of classical works. ${ }^{, 33}$

This statement of Brecht on inheritance and accounting [of classical works] reflects to a great extent the aesthetic conception of socialistic states that proposes the most significant artists as revolutionary in societal and humanitarian progress, and views socialistic society as the rightful bearer of that inheritance. Siegmund-Schultze asks whether we should break completely with inherited art works or whether the most valuable elements should be singled out, retained and further developed, and appeals for that further development. ${ }^{34}$ The working class will reach back to the best artistic traditions of the past, and will gradually link those with their own cultural accomplishments, which will then, little by little, become a factor. Close knowledge of past cultural achievements is indispensable for personal artistic development. Again and again, two statements are invoked in this connection, which say: "The proletarian culture must be the normative development of that totality of knowledge that humanity has evolved under the yoke of capitalistic society, of landowners, of civil servants. ${ }^{35}$ National solidarity in art also comes up in that regard: "Art belongs to the folk. It must have its deepest roots in the broad productive masses. It must be understood and loved by them. It must link the masses in their feeling, thinking, and volition. It must awaken and develop artists in the masses." 36 The socialistic cultural terrain thus develops through:

1. knowledge of the great accomplishments of the culture of the past

2. the critical evaluation and adoption of those accomplishments, as well as

3. the transformation of them into socialistic and communalistic art.

Consequently, the cultural inheritance must possess humanistic character, must have positive societal value, and must presuppose the setting of revolutionary goals. Accordingly, cultural

\footnotetext{
${ }^{33}$ Bert Brecht, Schriften zur Theaterarbeit, Band 7 (Berlin/Weimar, 1964), 342.

${ }^{34}$ cf. Siegmund-Schultze, "Die Rolle des musikalischen Erbes im Sozialismus," 15.

${ }^{35}$ W.I. Lenin, Über Kunst und Literatur (Berlin, 1960), 52.

${ }^{36}$ Lenin, Über Kunst und Literatur, $63 f$.
} 
standards are preserved and art works of the current culture in the GDR will not be overvalued without qualification. That would mean that Beethoven's ideals would be realized by means of the socialist movement. The artistic inheritance should not be altered according to the views and goals of socialism. However, certain evaluations should not be relinquished. Not every art of the past can be artistically valuable. Nevertheless, hidden treasures of art should be sought. However, they should not be presented to the public indiscriminately. In the case of "great" music no particularly deep anxiety should exist with regard to its thematic content. The statement "not ever word can stand as we use it" points to a certain helplessness in dealing with "problematic" works, e.g. in Bach's and Händel's sacred music. With Beethoven, we are in better shape, if there is success in justifying its socio-political commitment in his works. The romanticists are viewed as the founders of relevant national schools, which achieved their effect by means of a revolutionary, progressive attitude toward the struggle for liberation of its folk. New music possesses no societal value because the danger of, among other things, "typical manifestations of imperialistic cultural ideology" lies hidden in it. ${ }^{37}$

The task of music education should be to give the general public the conceptual content of socalled humanistic art works, and to awaken understanding for contemporary works. An example of a genealogical tradition of a musical genre is to show how the attempt is being undertaken in the GDR to bring contemporary art into the domain of "great" music. ${ }^{38}$

\begin{tabular}{|l|l|}
\hline Händel & $\begin{array}{l}\text { Messiah } \\
\text { ("highest humanization of the Christ legend”) }\end{array}$ \\
\hline Mozart & Zauberflöte \\
\hline Beethoven & Ninth Symphony \\
\hline Wagner & Meistersinger \\
\hline Meyer, E.H. & Mansfelder Oratorio \\
\hline
\end{tabular}

A Marxist-based musical analysis combines ideological and political issues with intellectual and aesthetic perspectives. In order to be able to understand a work of music, skills have to be developed which enable the independent preparation of a well-founded analysis, which additionally account for historical and ideal specification of individual works vis-a-vis the societal bonds of the composer. Michel asks:

For example, how could someone properly understand a Schubert lied with knowing Schubert's relation to society, to Metternich's national system, to Schubert's circle of friends, without being familiar with the special function of the lied in the case of Schubert? How often are such songs performed purely according to emotion, and how often, thereby, is the image of a composer of his times and the objective of his art misunderstood and distorted. ${ }^{39}$

From this quotation it is clear that the music educator should understand the composer based on the societal context, a not inessential aspect which, so it seems, is still often given short shrift in western music analysis.

\footnotetext{
${ }^{37}$ Ibid., 60.

${ }^{38}$ Ibid.

${ }^{39}$ Michel, "Die Aufgaben der Musikerziehung," 13.
} 


\section{The lied in music pedagogy in the GDR}

If in Western Europe the cultivation of folk music in primary schools leads a modest existence, in the GDR music education at least makes an effort to shape music instruction around the singing of folk songs. The objectives that are thereby pursued are, however, not purely musical. Rather, they are to build political consciousness.

\subsection{The politicization of the folk song}

Politicization of folk songs for the young applies in the GDR to all age groups. Even the cradlesong and lullaby are put in service of propaganda. The following conclusions are drawn from such politicization. ${ }^{40}$ Relationships are created between the folk song and environment, as well as between the song and life. Folk songs from the (GDR) Fatherland and homeland are promoted. Ethical problems are raised and inculcated in songs.

\begin{tabular}{|c|c|}
\hline \multicolumn{2}{|c|}{$\begin{array}{l}\text { Example 1: Deutsches Wiegenlied / German Cradlesong }{ }^{41} \\
\text { Text: Wera Skupin } \quad \text { Music: Kurt Schwaen }\end{array}$} \\
\hline Schlaf, mein Kind, schlaf ein. & Sleen my child fall asleen. \\
\hline Reicher als ein Märchenprinz & Richer than a fairy-tale prince \\
\hline Wirst du einmal sein. & You will some day be \\
\hline Schlaf, mein Kind, schlaf ein. & Sleep, my child, all asleep. \\
\hline Schlaf, mein Kind, schlaf ein. & Sleep, my child, fall asleep. \\
\hline $\begin{array}{l}\text { Alles, was in Deutschland ist, } \\
\text { wird des Volkes sein. }\end{array}$ & $\begin{array}{l}\text { Everything in Germany, } \\
\text { will be of the people. }\end{array}$ \\
\hline Schlaf, mein Kind, schlaf ein. & Sleep, my child, fall asleep. \\
\hline Wiegenlied & Cradlesong \\
\hline Schlafe, kleiner wilder Knabe! & Sleep, fierce little boy! \\
\hline Schließe deine Äuglein zu. & Close your little eyes. \\
\hline Träum von einer roten Fahne, & Dream of a red flag, \\
\hline Fahnenträger, der bist du! & Flag bearer, that is you! \\
\hline Träum von einem weiten Lande. & Dream of a spacious land. \\
\hline Viele rote Fahnen wehn. & Many red flags wave. \\
\hline Schiffe liegen dort am Strande, & Ships are moored on the beach, \\
\hline schnell bereit, in See zu gehen. & quickly ready to go to sea. \\
\hline $\begin{array}{l}\text { Bringen Butter, Erz, Traktoren. } \\
\text { Bringen sie für dich und mich. }\end{array}$ & $\begin{array}{l}\text { They bring butter, ore, tractors, } \\
\text { Bring them for you and me. }\end{array}$ \\
\hline
\end{tabular}

\footnotetext{
${ }^{40}$ cf. Musikerziehung als gesellschaftspolitische Funktion, ohne Autoren-, Orts- und Jahresangabe, 39.

${ }^{41}$ Based on Musik in der Schule, April 1952.
} 


\begin{tabular}{|l|l|}
\hline \multicolumn{2}{|l|}{$\begin{array}{l}\text { Example 2: Neue Freundschaft ist geboren / New friendship is born } \\
\text { Text and music: Arno Hartung }\end{array}$} \\
\hline $\begin{array}{l}\text { Neue Freundschaft ist geboren, } \\
\text { siegte über Tod und Krieg. }\end{array}$ & $\begin{array}{l}\text { New friendship is born, } \\
\text { vanquished death and war. }\end{array}$ \\
$\begin{array}{l}\text { Dieses dank dem weisen Stalin, } \\
\text { der in Liebe Tag und Nacht, } \\
\text { immer denkend, immer sorgend, } \\
\text { auch dein junges Glück bewacht. }\end{array}$ & $\begin{array}{l}\text { This is thanks to the wise Stalin, } \\
\text { who in love, day and night, } \\
\text { always thinking, always worrying, } \\
\text { guards also your young fortune. }\end{array}$ \\
$\begin{array}{l}\text { Dank es allen Sowjetmenschen. } \\
\text { Wachse! Lerne! Sei bereit! }\end{array}$ & $\begin{array}{l}\text { Thanks to all Soviet peoples. } \\
\text { Grow! Learn! Be prepared! } \\
\text { Die dein Heimatland befreit. }\end{array}$ \\
$\begin{array}{l}\text { Bear firmly the red flag } \\
\text { Which liberates your homeland. }\end{array}$ \\
\hline
\end{tabular}

This song was given a prize in the year 1951 in the artistic competition of the former society for German-Soviet Friendship. This propaganda becomes even more vivid in kindergarten songs.

\begin{tabular}{|l|}
\hline $\begin{array}{l}\text { Example 3: Aufbaulied, von Kindern zu singen/ } \\
\text { Construction song, to be sung by children } \\
\text { Music: Rheinhold Krug } \\
\text { Text: Martin Pohl }\end{array}$ \\
\begin{tabular}{l|l} 
Ziegel, Ziegel, ihr müsst wandern \\
$\begin{array}{l}\text { Von der einen Hand zur andern, } \\
\text { bis ihr alle Stein auf Stein } \\
\text { werdet aufgeschichtet sein. }\end{array}$
\end{tabular} \\
$\begin{array}{l}\text { Bricks, bricks, you should wander } \\
\text { From the one hand to the other, } \\
\text { until all of you, stone on stone, } \\
\text { are stacked up. }\end{array}$ \\
\hline
\end{tabular}

When the child begins school, it is familiarized with the usefulness of learning by means of song.

\begin{tabular}{|l|l|}
\hline $\begin{array}{l}\text { Example 4: Lied von der Klasse/Song of the class } \\
\text { Text: Carl Spannagel } \\
\text { Music: N.N. }\end{array}$ \\
\begin{tabular}{l|l} 
Tritt der Lehrer in die Klasse, \\
stehen wir auf:
\end{tabular} & $\begin{array}{l}\text { If the teacher enters the class, } \\
\text { we stand up: } \\
\text { "Guten Morgen!" schallt's. }\end{array}$ \\
$\begin{array}{l}\text { Rechnen, Schreiben, Lesen, Singen, } \\
\text { das macht uns Spaß, } \\
\text { ja, das macht uns Spaß. }\end{array}$ & $\begin{array}{l}\text { Math, writing, reading, singing, } \\
\text { that is fun for us, } \\
\text { yes, that is fun for us. }\end{array}$ \\
\hline
\end{tabular}

\footnotetext{
${ }^{42}$ Ibid.

${ }^{43}$ Ibid.

${ }^{44}$ Ibid.
} 
The so-called pioneer songs sing about life's optimism, as required by the ideologues.

\begin{tabular}{|c|c|}
\hline \multicolumn{2}{|c|}{$\begin{array}{l}\text { Example 5: Refrain des Pionierliedes/Refrain of the pioneer song }{ }^{45} \\
\text { Text and Music: Günter Kochan }\end{array}$} \\
\hline $\begin{array}{l}\text { Wir lieben unsere Heimat } \\
\text { Ja, wir sind junge Pioniere } \\
\text { Und die sind immer bereit, } \\
\text { um die Heimat zu vereinen } \\
\text { in Frieden und Einträchtigkeit. }\end{array}$ & $\begin{array}{l}\text { We love our homeland } \\
\text { Yes, we are young pioneers } \\
\text { And they are always ready } \\
\text { to unify the homeland } \\
\text { in peace and harmony. }\end{array}$ \\
\hline
\end{tabular}

The explanations of the curriculum for the subject music in the eighth grade indicate what value socialistic youth songs have in music education. ${ }^{46}$ Music as a subject is subdivided into units of material that encompass four hours. Using selected songs, the development of the GDR is to be laid out for the youth. The flow of instruction is prescribed down to the minute. The following quotation verifies how important non-musical aspects are as well.

Of special significance in the 1971-72 school year are the emphases on the material through references to the preparation and execution of the $10^{\text {th }}$ world festival of youth and students, 1973, in Berlin. In discussions about instruction, the beginning of preparations for the youth consecration and admittance into the Free German Youth is to be taken up. ${ }^{47}$

It was clear above that in the selection of songs the emphasis is on contemporary creations, but can also be reinforced by the following quotation.

An important aspect of socialistic education through music is the choice of songs. Music teachers must increasingly move toward utilizing the song resources of our time in instruction, especially songs of composers in our republic and in national-democratic countries....In addition to youth and large-rally songs, songs of the struggle of the working class should find more access in our instruction. $^{48}$

Furthermore, those songs in which western "maudlin sentimentality" and "mental kitsch" are evoked should be eliminated. ${ }^{49}$ The introduction to song and appropriate shaping of songs should give pupils proper insight into what is sung, where great value is placed on certain technical aids such as long-playing records and tape recordings. As in morning prayers in some village schools in western countries, the so-called morning song should be introduced in schools. New songs should come to the fore where possible. "All too often still, meaningless tear-jerkers displace our valuable song material," such as the Köhlerliesl and the Rennsteiglied. ${ }^{50}$ Such inherited songs are still well

\footnotetext{
${ }^{45}$ Based Musik in der Schule, April 1951.

46 cf. Günther Herold, “Die Wiederspiegelung der Entwicklung unserer Republik im sozialistischen Jugendlied,” in Musik in der Schule (Berlin/O, 1972), 331-333 and 339-341.

${ }^{47}$ Herold, "Die Wiederspiegelung der Entwicklung," 331.

${ }^{48}$ Manfred Frisch, "Das Lied in der sozialistischen Erziehung," in Musik in der Schule (Berlin/O, 1959), 193.

${ }^{49}$ Frisch, "Das Lied in der sozialistischen Erziehung," 194.

${ }^{50}$ These are two types of traditional German popular songs. A Rennsteiglied is a kind of hiking song (Wanderlied), a Köhlerliesel a social song, for parties, sometimes with amorous themes.
} 
known to most parents. The regret that parents make no effort to learn contemporary socialistic songs with their children cannot be ignored. Additionally, a certain significance is accorded to extracurricular singing in the singing movements of youth organizations and in the camps of schools and businesses. Only those songs should be chosen which "first, correspond to the educational goal of our socialistic school; second, in form and content are scientifically and artistically without fault; third, appropriate to the age characteristics of the children. ${ }^{51}$

\subsection{Inherited songs with new texts}

In a state system in which the relationship to culture and art tradition is unproblematic, the

question arises about justification and the possibility of providing old songs with new texts. ${ }^{52}$ The need for new song material is very large in the GDR. New events such as technological development, new country life, new forms of societal life are to be reflected through singing. Old songs, as representatives of conditions that are no longer desired merely interpret those things instead of having a modifying effect on the foundation, in the sense of interpreting the new model. Accordingly, old songs would be only be acceptable as comparisons.

The song "In March of the Farmers" sings of those conditions. However, the view of the new words does not justify the sung text. In the GDR, therefore, a new strophe is added.

Yes, it was once so, and the work was difficult.

Today tractors and threshers produce more

And if the fields were combined, the collective would outperform all others. ${ }^{53}$

In general, this raises the question whether it is justified willfully to alter inherited cultural resources. In the GDR, opinions on the matter are widely diversified. Some advocate the inviolability of inherited culture and stress the principle of cultivating and preserving it. Others refer to the fact that folk songs that are not fixed in print but rather are transmitted only orally are constantly subjected to the process of transformation. In this context, Lange quotes Stalin: "The folk refines its songs over centuries and elevates them to the highest level of art."54

It is known that often several versions of a text exist for one and the same melody, and that through contrafactum new text underlays are undertaken, and that secular songs are refunctionalized into sacred ones, and vice versa. As a pronounced example, Luther should be mentioned, who created reformist chorales out of folk songs, and later Bach, too, in his sacred and secular works. However, statements by the Bach biographer, Schweitzer, who several times calls such a procedure violent, barbaric and musically inappropriate bear witness that this procedure does not always meet with approval. ${ }^{55}$ Songs of the worker's struggle and political rally songs arose

\footnotetext{
${ }^{51}$ Reinhardt Syre, "Musische Erziehung in den Ferien,” in Musik in der Schule (Berlin/O, 1960), 212.

${ }^{52}$ Christian Lange, "Neue Texte zu alten Melodien?” in Musik in der Schule (Berlin/O, 1959), 197-208.

${ }^{53}$ Quoted according to Lange, "Neue Texte zu alten Melodien?” 198.

${ }^{54}$ Quoted according to Lange, ibid., 199.

55 cf. Albert Schweitzer, Johann Sebastian Bach (Leipzig, 1908).
} 
in that process. However, the alterations often applied to only a few words so that relearning would be easier because the melody of course remained unchanged.

Additionally, there are songs of struggle that made their way into German territories and quickly became popular. These were provided with German texts that relied heavily on the original text. Lange cautions against using contrafactum indiscriminately, but considers them ideally suitable, first, in order to have a parody effect and, second, in order to retain for the practice of singing the melody of a song that is especially striking in its musical beauty, and whose inherited text is too far removed from our societal conditions and tasks, i.e. from the understanding of our pupils. ${ }^{56}$

\section{Concluding Comment}

There is a difference between training and education in the GDR, even if I occasionally use the two concepts synonymously. Many essays deal with music education in general, more as music education in particular. The offerings in the literature on this theme is exceedingly rich. However, it runs chronologically only up to ca. 1972. Socialistic professional literature differs essentially from non-socialistic. The line of argumentation, which in almost all essays is the same, ends up such that socialistic propaganda occupies a significant place, which clearly runs counter to scholarly and didactic credibility. From that it is clear that in the GDR politics above all dictates the goal of all education, and pedagogy must provide the means for it. In the positive, the targeted search for and promotion of talent is to be highlighted. Schools of general education and music schools are integrated in that respect, but always on the premise that those to be promoted fit into the political system.

\footnotetext{
${ }^{56}$ Lange, “Neue Texte zu alten Melodien?” 208.
} 


\section{List of Literature}

Brecht, Bert. Schriften zur Theaterarbeit, Band 7. Berlin/Weimar, 1964.

Diezel, Günther. "Sozialistisches Menschenbild und Musikerziehung." In Musik in der Schule, 185-190. Berlin/O, 1971.

Gysi, Klaus. "Die Kunst im Kampf für eine sozialistische Gemeinschaft, Auszug aus einer Rede.” Neues Deutschland (19 October 1968), 3-4.

Hager, Kurt. “Arbeiterklasse und Künstler.” In Musik in der Schule, 314-317 and 383-387. Berlin/O, 1972.

Herold, Günther. "Die Wiederspiegelung der Entwicklung unserer Republik im sozialistischen Jugendlied.” In Musik in der Schule, 331-333 and 339-341. Berlin/O, 1972.

Hübner, Hellmut. "Bildungs- und Erziehungsaufgaben des Klavierunterrichts in der Musikschule und die Möglichkeit ihrer Erfüllung durch die Arbeit an Werken des sozialistischen Gegenwartsschaffens.” In Musik in der Schule, 73-81. Berlin/O, 1969.

Lange, Christian. “Neue Texte zu alten Melodien?” In Musik in der Schule, 197-208. Berlin/O, 1959.

Lenin, W.I. Über Kunst und Literatur. Berlin, 1960.

Ludwigs, Manfred. "Zur Organisation der Erziehung in der DDR.” In Deutsche Studien. Hrsg., Gehrmann, Karlheinz u. a., 125-138. Lüneburg, 1977.

Marx, Karl. Deutsche Ideologie, Feuerbach WWII, 23.

Michel, Paul. "Die Aufgaben der Musikerziehung im System der sozialistischen Allgemeinbildung." In Musik in der Schule, 5-18 and 49-56. Berlin/O, 1969.

Michel, Paul. "Musik und Jugend.” In Musik und Gesellschaft, 88-99. Berlin/O, 1969.

Michel, Paul. "Musik und Hörer in unserer Zeit. Psychologische und pädagogisch-methodische Grundfragen der Musikverbreitung.” In Deutscher Kulturbund, 261-265. Berlin/O, 1967.

Neuner et al. "Zur Bilanzierung des Standes der Theorie der Allgemeinbildung." In Pädagogische Forschung, Wissenschaftliche Nachrichten, 3-47. Ohne Autorenangabe. Berlin/O, 1968.

Musikerziehung als gesellschaftspolitische Funktion, ohne Autoren-, Orts- und Jahresangabe, 40 pages.

Schmollack, Jürgen. "Sozialistisches Menschenbild und sozialistische Erziehung.” In Pädagogik, 824-837. Berlin/O, 1968.

Schweitzer, Albert. Johann Sebastian Bach. Leipzig, 1908.

Siegmund-Schultze, Walther. "Die Rolle des musikalischen Erbes im Sozialismus." In Musik in der Schule, 1: 15-27 and 2: 53-64. Berlin/O, 1963.

Siegmund-Schultze, Walther. Ziele und Aufgaben der sozialistischen Musikerziehung. Leipzig, 1960.

Syre, Reinhardt. "Musische Erziehung in den Ferien." In Musik in der Schule, 212. Berlin/O, 1960. 


\section{Further List of Literature}

(with no direct reference to the text)

Archangelski, Leonid. Sozialismus und Persönlichkeit. Berlin/O, 1980.

Diezel, Günther. "Für eine parteiliche, lebensverbundene Musikerziehung." In Musik in der Schule, 234236. Berlin/O, 1963.

Diezel, Günther. "Singen und sozialistische Bewusstseinsbildung." In Musik in der Schule, 95-100. Berlin/O, 1971.

Engel, Otto. "Die Bedeutung der Musikerziehung für die Allgemeinbildung sozialistischer Menschen.” In Musik in der Schule, 349-352. Berlin/O, 1959.

Frisch, Manfred. "Das Lied in der sozialistischen Erziehung." In Musik in der Schule, 193-197. Berlin/O, 1959.

Grabs, Manfred. "Im Sozialismus handelt es sich vor allem um Erziehung.” In Musik in der Schule, 317320. Berlin/O, 1972.

Hanke, Helmut. "Sozialistisches Gesellschaftssystem und sozialistische Kultur.” In Musik in der Schule, 393396. Berlin/O, 1969.

John, Eduard. "Sozialistisches Menschenbild und humanistische Tradition." In Das sozialistische Menschenbild. Hrsg., Elmar Faber und Eduard John, 4-74. Leipzig, 1968.

Kaden, Werner. "Der Beitrag des Musikunterrichts zur ästhetischen Bildung und Erziehung.” In Musik in der Schule, 49-53. Berlin/O, 1971.

Kurella, Alfred. "Musische Erziehung-Bestandteil unseres sozialistischen Lebens.” In Musik in der Schule, 98-107. Berlin/O, 1959.

Laffin, E. "Musik als Mittel sozialistischer Erziehung." In Neue Erziehung im Kindergarten, 15-22. Berlin/O, 1968.

Pollatschek, Walter. "Agitrop - das revolutionäre Theater der Arbeiterklasse.” In Musik in der Schule, 226233. Berlin/O, 1959.

Rühle, Otto. "Klassisches Humanitätsideal und sozialistisches Menschenbild." In Das sozialistische Menschenbild. Hrsg., Elmar Faber und Eduard John, 55-74. Leipzig, 1968.

Schmidt, Gerhard. "Perspektiven unserer sozialistischen Musikkultur." In Musik in der Schule, 124-126. Berlin/O, 1969.

Wunder, Wolfgang. "Musikerziehung und sozialistisches Musikschaffen.” In Musik in der Schule, 368-371. Berlin/O, 1971. 


\begin{abstract}
Following an overview of the general organization and conception of educational institutions, I will discuss more closely the development of the socialist notion of humankind through music education. Then I will present, explain, and comment on some ideas in a West German essay that deals with music education in both German states. The domains of music tradition and music reception are not without problems in socialist music education. A few aspects will be discussed in that connection. Songs, as the most important means of education in music pedagogy in the German Democratic Republic, are "re-functionalized" for political purposes. The politicization of songs and the new text underlay of inherited songs will also be discussed.
\end{abstract}

